\title{
The Role of Gene Mutations Detection in Defining the Spectrum of B - Thalassemia in Various Ethnic Regions
}

\author{
Fakher Rahim ${ }^{1}$, Najmaldin Saki²,3 and Mohammad Ali Jalalai far 2,3 \\ ${ }^{1}$ Endocrinology and Metabolism Research Center (EMRC), \\ Tehran University of Medical Sciences, Tehran \\ ${ }^{2}$ Department of Medical Laboratory Science, \\ Ahvaz Jundishapur University of Medical Sciences, Ahvaz \\ ${ }^{3}$ Thalassemia and Hemoglobinopathies Research Center, \\ Ahvaz Jundishapur University of Medical Sciences, Ahvaz
}

Iran

\section{Introduction}

The thalassemia is a widespread with about $5 \%$ of the world population affected by it and is found in some 60 countries, with the highest prevalence in the Mediterranean region, parts of North and West Africa, the Middle East, the Indian subcontinent, southern Far East and south-eastern Asia, together comprising the so-called thalassemia belt. In western countries, thalassemia affects mostly individuals whose ancestry is traceable to high prevalence areas. As an example, there are around 1,000 cases of $\beta$-thalassemia major in the United States, most of whom are descendants of Mediterranean, Asian Indian, South Asian or Chinese ancestors. This figure is even less than half of the number of $\beta$-thalassemic patients in Fars Province, a region only 120,000 km 2 large in southern Iran (Haghshenas and Zamani, 1997; Rahim et al., 2007). The gene frequency of $ß$-thalassemia, however, is varies from area to area, having its highest rate of more than $10 \%$ around the Caspian Sea and Persian Gulf. The prevalence of the disorder in other areas is between 4-8\% (Rahim and Abromand, 2008). There are many genes coding for the globins. They are found on chromosome 11 ( $\beta$-globin cluster) or chromosome 16 (a-globin cluster) figure1.

\subsection{Beta-Thalassemia}

Beta-Thalassemia, one of the most widespread genetic diseases in the world, is a common autosomal recessive disorder caused by point mutations in the $B$ - globin gene that is located as a cluster on the short arm of chromosome 11 (Weatherall et al., 1989; Sack, 1999; Oliveri, 1999). More than 200 different mutations affecting diverse levels of beta-globin genes expression have so far been identified (Trent, 1997; Ho and Thein, 2000). South-western region of Iran also represented various B-thalassemia mutations (Figure 2). Different strategies of classification individuals genotypes by B-globin gene cluster and cloning nucleotides sequencing lead to identification of several mutations in Mediterranean (Orkin et al., 1982), Asian Indians (Kazazian et al., 1984, Ohba et al., 1997), American Blacks 
(Antonarakis et al., 1984) and Chinese (Cheng et al., 1984). The global distribution indicates a high prevalence in a belt around the earth, which is around the 40th parallel in the Mediterranean area but eastwards moves further south, reaching the equator in Indonesia. More than two million carriers of $ß$-thalassemia live in Iran. The Iranian populations are mixture of different ethnic groups.

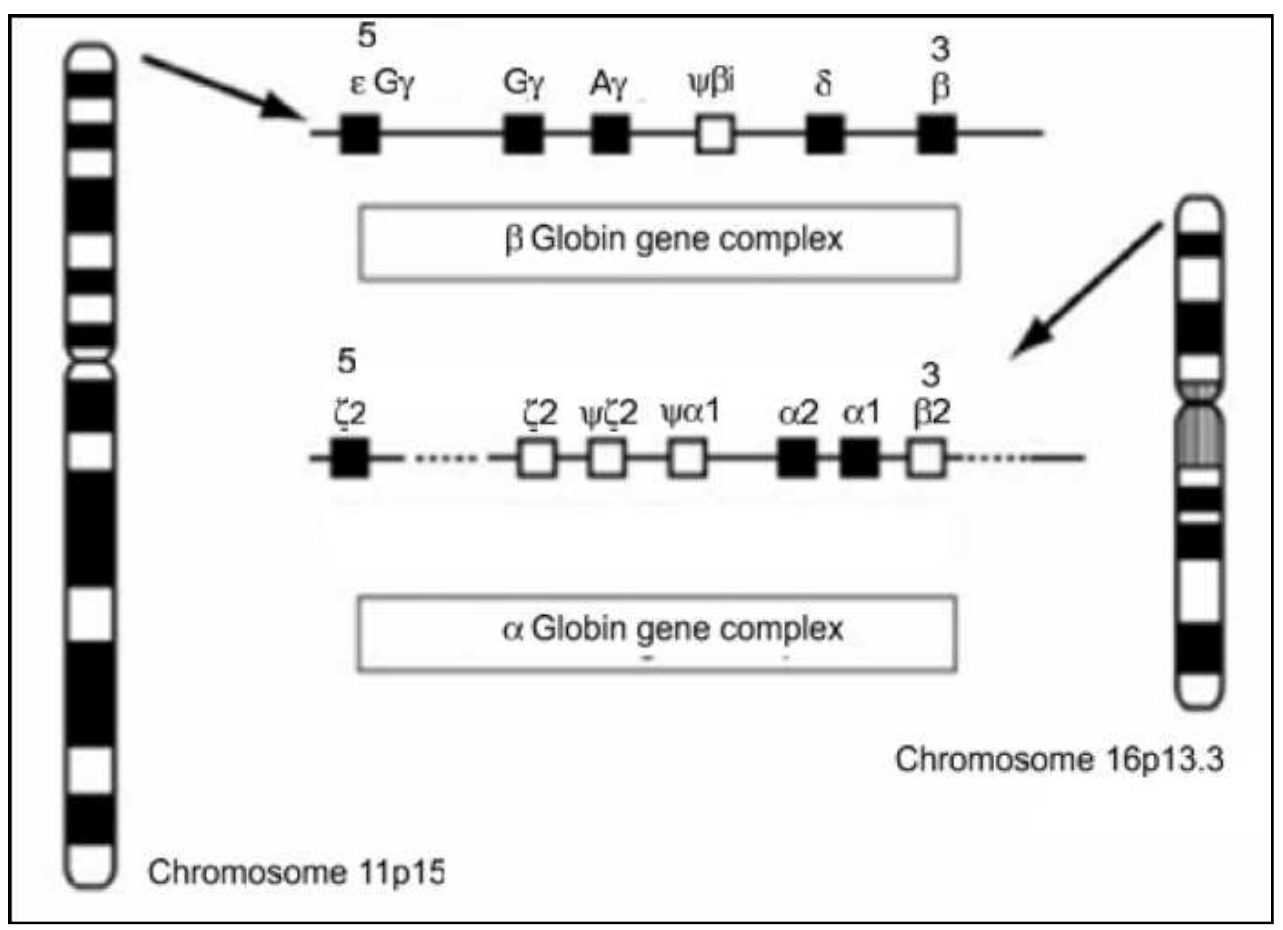

Fig. 1. Two globin gene clusters including $\alpha$ - and $\beta$ - represented here. 


\subsection{Alpha thalassemia}

Alpha thalassemia disorders are a group of hereditary anemias caused by absent or decreased production of the alpha chain of hemoglobin (Hb) (Vichinsky, 2009). freeAll affected individuals have a variable degree of anaemia (low $\mathrm{Hb}$ ), reduced mean corpuscular hemoglobin $(\mathrm{MCH} / \mathrm{pg})$, reduced mean corpuscular volume $(\mathrm{MCV} / \mathrm{fl})$ and a normal/slightly reduced level of $\mathrm{HbA} 2$. Molecular analysis is usually required to confirm the hematological observations (especially in silent alpha thalassemia and a-thalassemia trait). A single gene, two-gene, three-gene or four-gene deletions result in alpha thalassemia silent carrier status, thalassemia trait (minor), $\mathrm{HbH}$, and hemoglobin Bart's ( $\mathrm{Hb}$ Bart's), respectively (Figure 3).

\section{Bar Chart}

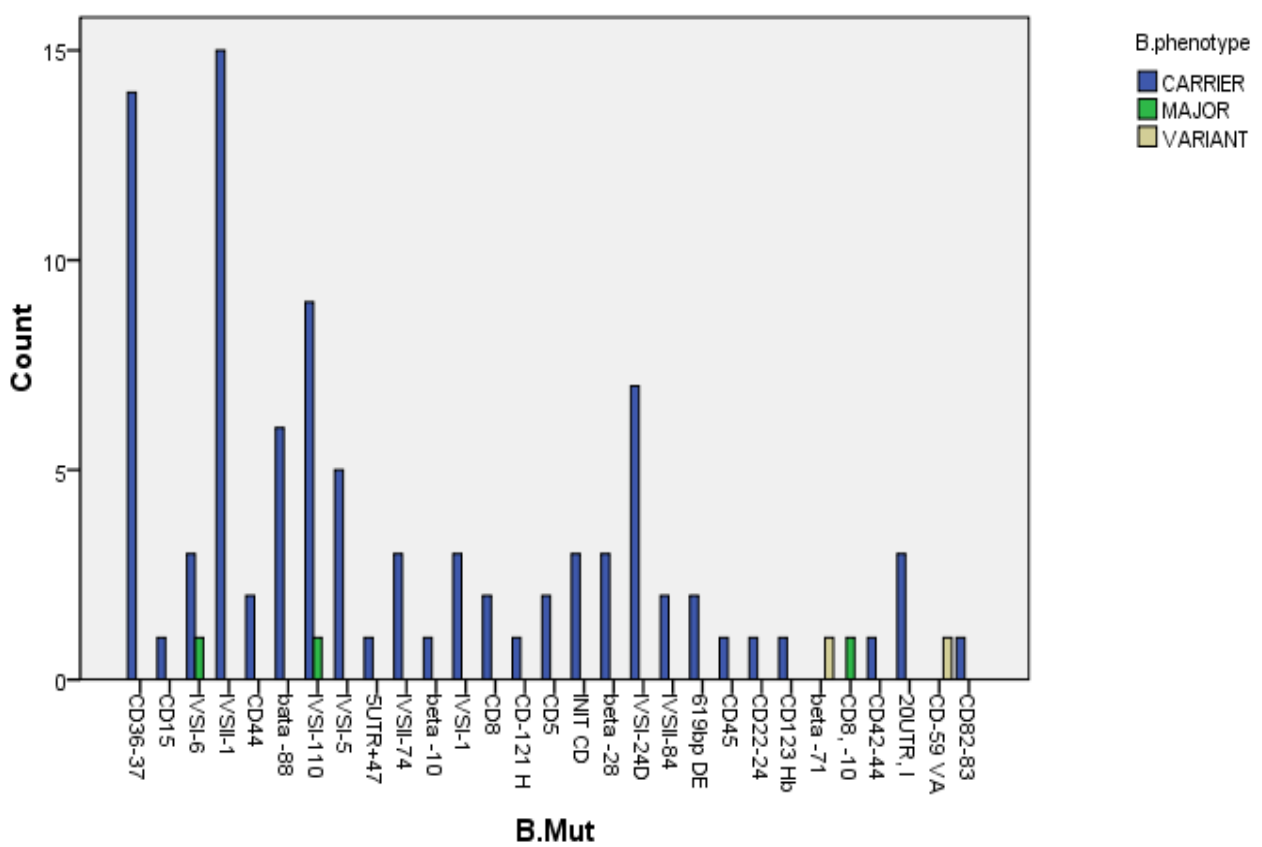

Fig. 2. Different B-thalassemia mutations detected in our region of study (South-western region of Iran), different explained groups are carrier, which represents the heterozygous type; Major, which represents the homozygous type; Variants, which represents the hemoglobin variants 


\section{Bar Chart}

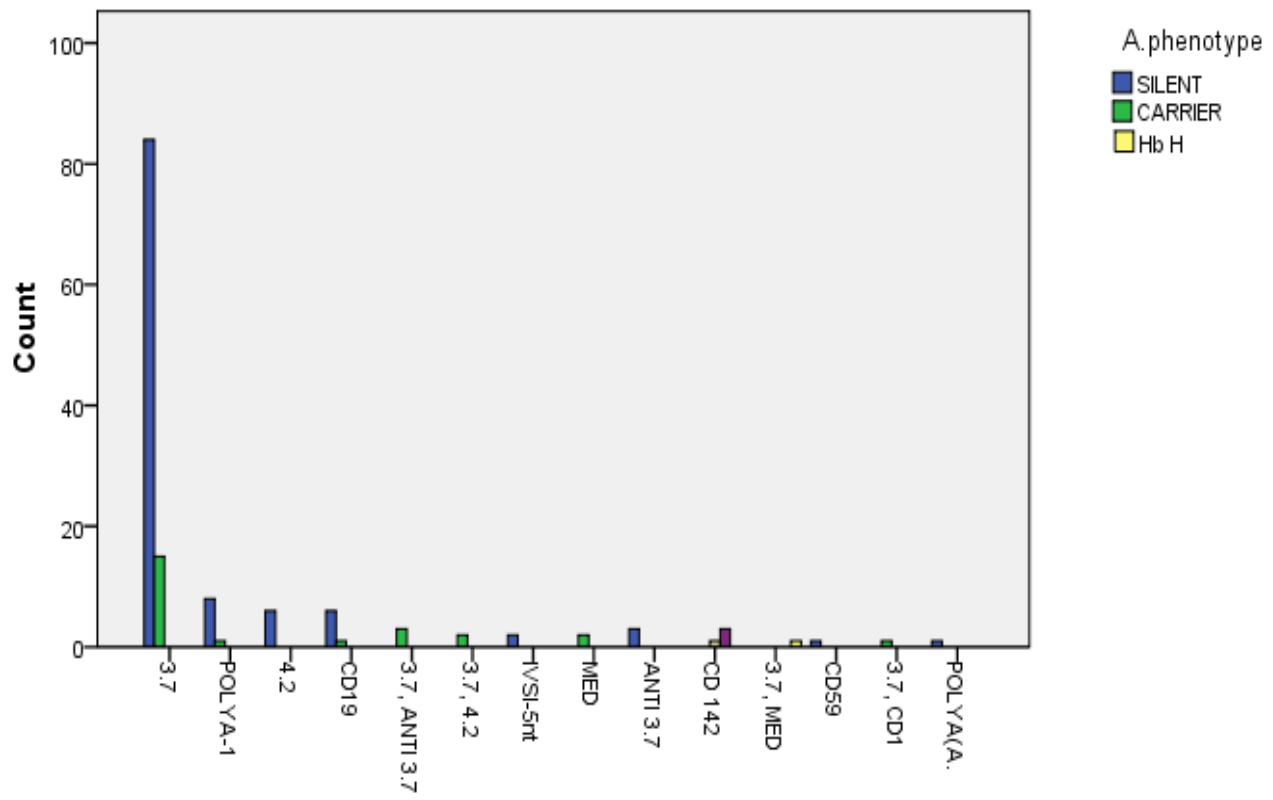

A.Mut

Fig. 3. Different a -thalassemia mutations detected in our region of study (South-westernregion of Iran), different explained groups are carrier, which represents the heterozygous type; Major, which represents the homozygous type; $\mathrm{HbH}$, Hemoglobin $\mathrm{H}$ disease

\subsection{Thalassemia intermedia}

Thalassemia intermedia are a clinical phenotype which displays marked genotypic variability in different populations or ethnic groups (Panigrahi et al., 2009). This disorder is a clinical designation often used to characterize individuals who are homozygous for bthalassemia genes but maintain hemoglobins of 6-9 g/dL without regular transfusions (Galanello et al., 2001). They have more severe RBC morphological abnormalities than the trait, as well as varying degrees of splenomegaly, thrombosis and skeletal changes (Taher et al., 2008).

\subsection{Hemoglobin $\mathrm{H}$ ( $\mathbf{H b ~ H )}$}

Hemoglobin $\mathrm{H}(\mathrm{Hb} \mathrm{H})$ disease is the most common form of thalassemia intermedia. $\mathrm{Hb} \mathrm{H}$ (beta4) disease results from double heterozygosity for alpha(0)-thalassemia due to deletions that remove both linked alpha-globin genes on chromosome 16, and deletional alpha(+)thalassemia from single alpha-globin gene deletions (--/-alpha). However, $\mathrm{Hb} \mathrm{H}$ disease may occur from interactions between alpha (0)-thalassemia with nondeletional mutations or with abnormal hemoglobins such as Hb Constant Spring, Hb Paksé, Hb Quong Sze, and $\mathrm{Hb}$ Pak Num Po (Fucharoen and Viprakasit, 2009). 


\subsection{Hemoglobin $(\mathrm{Hb})$ Bart's}

Hemoglobin $(\mathrm{Hb})$ Bart's hydrops fetalis is a generally fatal intrauterine condition associated with homozygous alpha (0)-thalassemia. It is moderately insoluble, and therefore accumulates in the red blood cells (Karnpean et al., 2009; Singer, 2009).

\subsection{Simultaneous $\alpha$-and $\beta$-thalassemia}

Some case of complex beta- and alpha-thalassemia coinheritance is described. The chance of finding an individual with co-inheritance of $\alpha^{0}$ - and $\beta$-thalassemia is theoretically $1: 1000$. In other words, one in every 25 b-thalassemia carriers co-inherits $\mathrm{a}^{0}$ - thalassemia (Rahim, 2010; Rahim et al., 2008). Routine screening testing, such as mean cell volume (MCV) and $\mathrm{Hb}$ A2 level, cannot distinguish double heterozygotes for a and $\beta$-thalassemia from the pure $\beta$ thalassemia heterozygotes. The $\alpha^{0}$-thalassemia can be distinguished simply from double $\alpha^{0}-$ and $\beta$-thalassemia by a normal $\mathrm{Hb} \mathrm{A} 2$ level (Table 1 ).

\begin{tabular}{|c|c|c|c|c|c|c|c|c|c|c|}
\hline Case & Sex & $\begin{array}{l}\text { Age } \\
(\mathrm{Y})\end{array}$ & $\begin{array}{c}\mathrm{Hb} \\
(\mathrm{g} / \mathrm{dl})\end{array}$ & $\operatorname{MCV}(\mathrm{fl})$ & $\mathrm{MCH}(\mathrm{pg})$ & $\mathrm{HbF}(\%)$ & $\mathrm{HbA} 2(\%)$ & $\begin{array}{c}\mathrm{a}- \\
\text { genotype }\end{array}$ & $\begin{array}{c}\beta- \\
\text { genotype }\end{array}$ & $\mathrm{HbH}$ \\
\hline 1 & M & 24 & 13.9 & 72.1 & 23.4 & 1.1 & 5.3 & $-a^{3.7} / a a$ & A & - \\
\hline 2 & $\mathrm{M}$ & 32 & 11.7 & 70.7 & 22.6 & 0.4 & 5.1 & $-\mathrm{a}^{3.7} / \mathrm{ad}$ & B & - \\
\hline 3 & M & 29 & 11.4 & 73.0 & 22 & 0.5 & 5.1 & $\begin{array}{c}-\mathrm{a}^{3.7} / \mathrm{-} \\
\mathrm{a}^{3.7}\end{array}$ & $\mathrm{C}$ & - \\
\hline 4 & $\mathrm{~F}$ & 27 & 11.9 & 71.5 & 22.6 & 1.5 & 4.2 & $\alpha a /-a^{4.2}$ & $\mathrm{D}$ & - \\
\hline 5 & $\mathrm{~F}$ & 30 & 10.4 & 65.0 & 21 & 1.4 & 4.5 & $-\alpha^{3.7} / \alpha a$ & $E$ & - \\
\hline 6 & $\mathrm{~F}$ & 25 & 11.7 & 61.4 & 19.8 & 0.9 & 4.3 & $-\mathrm{a}^{3.7} / \mathrm{\alpha a}$ & $\mathrm{F}$ & - \\
\hline 7 & $\mathrm{~F}$ & 23 & 13.2 & 69.7 & 23.2 & 1.3 & 5.3 & $\begin{array}{c}\text { ad / - - } \\
\text { MED }\end{array}$ & G & - \\
\hline 8 & $\mathrm{M}$ & 29 & 11.5 & 75.5 & 23.2 & 1.9 & 4.9 & $\alpha \alpha /-\alpha^{4.2}$ & $\mathrm{H}$ & - \\
\hline 9 & $\mathrm{M}$ & 27 & 13.3 & 67.3 & 22.6 & 1.4 & 5.5 & $\begin{array}{c}\text { ad / - - } \\
\text { MED }\end{array}$ & I & + \\
\hline 10 & M & 29 & 11.1 & 69.5 & 23.8 & 0.9 & 5.4 & $\begin{array}{c}\text { ad / - - } \\
\text { MED }\end{array}$ & $\mathrm{J}$ & + \\
\hline
\end{tabular}

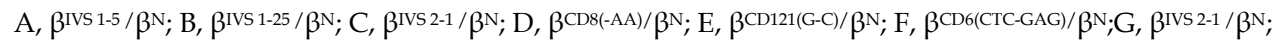

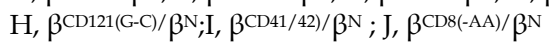

Table 1. Hematologic and genotypic findings in the 10 double heterozygotes for $\alpha-$ and $\beta$ thalassemia

\subsection{Co-inheritance of $\alpha$-and hemoglobin variants}

The chance of finding an individual with co-inheritance of $\mathrm{a}^{0}$ - thalassemia with different hemoglobin variants is also presented. In other words, this chance and presentation is rare (Rahim, 2009).

\section{Diagnosis}

The key to successful detection and characterization of the hemoglobinopathies, particularly the thalassemias, is the initial hematological data. The clue for a thalassemia comes with a low mean corpuscular volume (MCV) or mean corpuscular hemoglobin $(\mathrm{MCH})$. Although 
iron deficiency is the other explanation for a low $\mathrm{MCV}$ or $\mathrm{MCH}$, it is likely that this finding will point to thalassemia in regions of countries with at-risk ethnic populations (Table 2).

\begin{tabular}{lccc} 
Group (number of cases) & $\begin{array}{c}\text { Hb mean } \pm \text { SD } \\
\text { (Range) }\end{array}$ & $\begin{array}{c}\text { MCV mean } \pm S D \\
\text { (Range) }\end{array}$ & $\begin{array}{c}\text { MCH mean } \pm S D \\
\text { (Range) }\end{array}$ \\
\hline Beta-thalassemia Trait(171) & $9.53 \pm 1.43$ & $62.9 \pm 5.3$ & $20.03 \pm 1.80$ \\
& $(5.60 \cdot 12.10)$ & $(49 \cdot 78.90)$ & $(15 \cdot 26)$ \\
Beta-thalassemia Major(13) & $7.5 \pm 1.34$ & $71.6 \pm 5.20$ & $22.9 \pm 2.1$ \\
& $(5.20 \cdot 9.28)$ & $(63 \cdot 79)$ & $(20.9 \cdot 25.6)$ \\
Iron deficiency(42) & $7.75 \pm 2.05$ & $69.35 \pm 6.95$ & $17.52 \pm 2.84$ \\
& $(4.3 \cdot 12.95)$ & $(52.0 \cdot 77.8)$ & $(12.10 \cdot 23.12)$ \\
Alpha-thalassemia Trait(88) & $11.1 \pm 1.25$ & $73.6 \pm 4.67$ & $23.9 \pm 1.82$ \\
& $(9.20 \cdot 12.25)$ & $(60 \cdot 79)$ & $(19 \cdot 26.20)$ \\
Hb Variants(11) ${ }^{*}$ & $12.1 \pm 2.63$ & $73.9 \pm 4.4$ & $23.5 \pm 1.65$ \\
& $(7.8 \cdot 15.20)$ & $(66 \cdot 79)$ & $(21 \cdot 26.5)$ \\
\hline
\end{tabular}

*Includes hemoglobin $\mathrm{S}(\mathrm{HbS})$, hemoglobin $\mathrm{C}(\mathrm{HbC})$ and hemoglobin DPunjab (HbDPunjab)

Table 2. Hematological parameters in different groups with microcytic hypochromic anemia

\subsection{Differential diagnosis of beta-thalassemia}

We can differentiate $\beta$-thalassemia from other disorders such as iron deficiency anemia with the help of discriminate indices including Mentzer Index, England and Fraser Index, Srivastava Index, Green and King Index, Shine and Lal Index, red blood cell (RBC) count, red blood cell distribution width index (RDWI), Mean Density of Hemoglobin per Liter of blood (MDHL) and mean cell hemoglobin density (MCHD) (Rahim and Keikhaei, 2009). If iron deficiency is present, it is essential to correct this and then repeat the full-blood count and all other investigations. The first step after the initial abnormal blood count is to exclude iron deficiency and if present, to treat it. The blood count is then repeated and if the $\mathrm{MCV} / \mathrm{MCH}$ remains low, a thalassemia is most likely. Therefore, ferritin levels (and if necessary serum iron, iron binding capacity and percentage saturation) are sought. This is recommended because at times, particularly during pregnancy, it is possible that iron stores will be low or, in the presence of iron deficiency, it is possible that the MCV or MCH are influenced by the iron deficiency. It is also occasionally seen that the $\mathrm{HbA}_{2}$ level can be falsely lowered by iron deficiency. In this context there are special hemoglobin tests which may help in the primary detection scenarios (Table 3).

\subsection{Molecular diagnostic methods}

Almost all the methods for DNA analysis of the hemoglobinopathies used today are based on the polymerase chain reaction (PCR). Different well-known and applied methods have been described in table 4 . Therefore whether a mutation is a deletion, a rearrangement or a point mutation, a similar test will be performed with the variability and specificity coming 
The Role of Gene Mutations Detection in

\begin{tabular}{|c|c|c|}
\hline$\overline{\text { Test }}$ & What does it measure or detectY & What does it mean \\
\hline HbEPG & $\begin{array}{l}\text { Electrophoresis of globin proteins. Different techniques } \\
\text { possible from gel or membrane-based kits to } \mathrm{HPLC} \text {. } \\
\text { Abnormal bands apart from the usual } \mathrm{HbA}, \mathrm{HbF} \text { and } \\
\mathrm{HbA}_{2} \text { peaks can be detected }\end{array}$ & $\begin{array}{l}\text { (1) Gives some idea of the } \mathrm{HbA}_{2} \text { level but more } \\
\text { importantly (2) identifies if there are any variant } \mathrm{Hbs} \\
\text { - particularly } \mathrm{Hbs} \text { such as } \mathrm{HbE} \text { and } \mathrm{HbS} \text {. }\end{array}$ \\
\hline $\mathrm{HbA}_{2}$ & $\begin{array}{l}\text { Globin electrophoresis and quantization of the } \mathrm{HbA}_{2} \\
\text { peak. Different techniques used from membrane or } \\
\text { column-based kits to the more universally suited HPLC } \\
\text { are in use. }\end{array}$ & $\begin{array}{l}\text { A raised } \mathrm{HbA}_{2} \text { is the key parameter indicating the } \\
\text { presence of } \beta \text {-thalassemia. It is said that variant } \mathrm{Hbs} \\
\text { can raise the } \mathrm{HbA}_{2} \text { but this must be a rare event. } \\
\text { More of an issue is the borderline normal-raised } \\
\mathrm{HbA_{2 }} \text { because this might indicate silent } \\
\beta \text {-thalassemia. A low } \mathrm{HbA}_{2} \text { is also important to note } \\
\text { as this might indicate } \delta \text { thalassemia }\end{array}$ \\
\hline $\mathrm{HbF}$ & $\begin{array}{l}\text { Globin electrophoresis and quantization with different } \\
\text { methods available for the latter. }\end{array}$ & $\begin{array}{l}\text { A slightly raised } \mathrm{HbF} \text { to } 2-3 \% \text { (normal is }<1 \% \text { in an } \\
\text { adult) might indicate heterocellular HPFH or may be } \\
\text { a subtle pointer to an underlying silent } \\
\beta \text {-thalassemia. } \mathrm{HbF} \text { levels } 5 \% \text { and above are more } \\
\text { likely to be due to } \delta \beta \text { thalassemia or HPFH } \\
\text { (heterocellular or pancellular). In the case of } \\
\delta \beta \text { thalassemia or deletional HPFH one would } \\
\text { expect the } \mathrm{HbA}_{2} \text { level to be low. }\end{array}$ \\
\hline Kleihauer & $\begin{array}{l}\text { Red blood cells are stained to detect } \mathrm{HbF} \text {. This test is } \\
\text { used to distinguish heterocellular from pancellular } \\
\text { HPFH. }\end{array}$ & $\begin{array}{l}\text { Not a particularly useful test for distinguishing the } \\
\text { types of HPFH because these are very rare and } \\
\text { most laboratories are not sure how to interpret the } \\
\text { results. The only practical value for a Kleihauer stain } \\
\text { might be in fetal blood sampling to confirm that } \\
\text { maternal blood has not contaminated a fetal sample } \\
\text { (the latter would be homogeneously stained for } \\
\mathrm{HbF} \text { ). Any cells not staining for HbF would represent } \\
\text { maternal blood. }\end{array}$ \\
\hline $\mathrm{HbH}$ inclusions & $\begin{array}{l}\text { Red blood cells are stained to detect } \mathrm{HbH} \text { inclusions } \\
\text { (aggregates of } \beta \text { globin protein) }\end{array}$ & $\begin{array}{l}\text { Requires patience and skill to find the } \mathrm{HbH} \\
\text { inclusions and even with a } 2 \text {-gene deletion } \\
\alpha \text { thalassemia, only } 1-2 \text { such inclusions might be } \\
\text { found after a search lasting many minutes. There } \\
\text { fore, } \mathrm{HbH} \text { inclusions are easy to miss if the labora } \\
\text { tory is inexperienced or the individual looking down } \\
\text { the microscope does not spend enough time } \\
\text { searching for these inclusions. }\end{array}$ \\
\hline $\begin{array}{l}\text { Sickle solubility and } \\
\text { instability tests }\end{array}$ & $\begin{array}{l}\text { Various tests ranging from biochemical to } \\
\text { immunoassay are used to detect } \mathrm{HbS} \text { and unstable } \\
\text { variant } \mathrm{Hbs}\end{array}$ & $\begin{array}{l}\mathrm{HbS} \text { diseases as well as interactions of } \mathrm{HbS} \text { with } \\
\beta \text {-thalassemia are increasingly being detected in } \\
\text { many Iranian cities. Therefore, efficient and accurate } \\
\text { tests for sickling (sickle solubility, HbEPG) are } \\
\text { important components of the hemoglobinopathy } \\
\text { workup. }\end{array}$ \\
\hline
\end{tabular}

Table 3. Special hematologic tests requested once a hemoglobinopathy is suspected based on family history and/or full-blood count.

from the primers used. The sensitivity and specificity of PCR has revolutionized the molecular diagnostic field. It has almost eliminated the use of radioactive isotopes for detecting sequences and has enabled diagnosis to be made on much smaller quantities of DNA. The PCR-based techniques used in hemoglobin diagnostics include allele-specific oligonucleotide (ASO) hybridization or dot-blot analysis, reverse dot-blot analysis, allelespecific priming or amplification refractory mutation system (ARMS), restriction enzyme analysis, amplification created restriction analysis, mutagenically separated PCR and gapPCR. These PCR-based techniques are useful for identifying a known mutation; PCR-based approaches for scanning or screening for unknown mutations take advantage of altered conformation of single-stranded DNA and include denaturing gradient gel electrophoresis (DGGE), single-strand conformation polymorphism (SSCP) and heteroduplex analysis. The characteristic altered patterns of migration and their position in the scanning methods act as a guide for the location of the mutation, targeting the region for identification by other 
means. The ultimate method of mutation identification is by direct sequence analysis of specifically amplified DNA. In the last decade, the use of automated sequencers has led to nonradioactive, more robust and more rapid sequencing, making it suitable as a routine diagnostic tool. Direct sequencing analysis is particularly applicable to the globin genes which are compact and relatively small $(1.2-1.6 \mathrm{~kb})$ with most of the point mutations within the gene or its flanking sequences (Fakher et al., 2006).

Southern blotting is one of the few non-PCR based molecular techniques that still have a significant role to play in the molecular diagnosis of the hemoglobinopathies. It is very useful in the screening for large deletions or rearrangements and is essential in characterizing novel deletions. The more common deletions can be detected by gap-PCR once the deletion break points have been defined and specific primers flanking the deletion designed. Each of these techniques has its own limitations; the particular repertoire chosen by a laboratory for molecular diagnosis of the hemoglobinopathies depends on the spectrum of mutations encountered in their catchment area and the technical expertise available in the diagnostic laboratory. It is good practice for any DNA diagnostic laboratory to have at least two alternative methods for detecting each mutation (Vrettou et al., 2003).

\subsection{Prenatal Diagnosis (PND) \& Foetal DNA analysis}

Although historically, the prevention program, abortion, was considered unacceptable in Iran, intensive consultation led to the clerical approval of induced abortion in cases with $\beta$ thalassemia major in 1997, and a nationwide prevention program with screening, counseling and prenatal diagnosis (PND) network has been developed (Najmabadi et al., 2006 ;Rahim et al., 2007) (Table 4). Many laboratories offering DNA diagnostics of the $\mathrm{Hb}$ disorders are also involved in analysis of fetal DNA for the prenatal diagnosis of these disorders. Fetal DNA is usually and preferably, obtained through chorionic villus sampling in the first trimester of pregnancy (10-12 weeks). Chorionic villus sampling provides a good yield of DNA which is isolated using conventional methods of phenol chloroform extraction after careful microscopic dissection to remove any contaminating maternal deciduas. Occasionally, if the sample is too small, it may need to be cultured increasing the risk of maternal contamination. Amniocytes obtained in the second trimester can also be used as a source of fetal DNA but the fetal cells are often contaminated with maternal cells and the results have to be interpreted with caution after analysis for maternal contamination.

Every prenatal diagnosis should be accompanied by copies of haematology results of the parents and prior confirmation of the parental phenotypes and genotypes. The PCR-based techniques that best suit the expertise of the laboratory are then used to screen for the presence of the parental mutations in the fetal DNA. Parental, appropriate positive and negative controls must always be included in the investigations. A limited number of PCR cycles (25-28) should be performed to avoid amplification of any minor DNA species and to minimize amplification of any contaminating maternal DNA. As an added precaution, maternal DNA contamination should be checked for by using polymorphic DNA markers including the variable tandem repeats (VNTRs) such as ApoB and the short tandem repeats or micro satellites. This is particularly important when the fetal genotype is the same as the maternal genotype. Fetal DNA analysis should also be performed in duplicate and confirmed by an independent PCR-based technique. To confirm maternal DNA contamination we used polymorphic DNA markers including the variable tandem repeats (VNTRs) in all cases. 


\begin{tabular}{|c|c|c|c|c|c|}
\hline Mutation & Type & Ethnic origin & $\begin{array}{c}\text { Heterozygous } \\
\text { cases }\end{array}$ & $\begin{array}{l}\text { Homozygote } \\
\text { cases }\end{array}$ & $\begin{array}{l}\text { No. of } \\
\text { chromosomes } \\
\text { (\%frequency) }\end{array}$ \\
\hline Fr 36/37(-T) & $\beta O$ & Kurd, Iranian & 16 & 6 & $28(14.7)$ \\
\hline IVS $2-1(G$ to $C)$ & $\beta 0$ & Iranian & 14 & 7 & $28(14.7)$ \\
\hline$C D 6(\mathrm{Hb} S)$ & Bs & - & 4 & 9 & $22(13)$ \\
\hline IVS $1-110$ (G to A) & $\beta+$ & Mediterranean & 5 & 5 & $15(8.8)$ \\
\hline IVS 1-6 $(T \rightarrow C)$ & $\beta+$ & Mediterranean & 0 & 5 & $10(5.89)$ \\
\hline CD $44(-C)$ & $\beta 0$ & $\begin{array}{c}\text { Kurdish } \\
\text { Asian Indian, SE }\end{array}$ & 4 & 2 & $8(4.7)$ \\
\hline IVS $1-5$ (G to C) & $\beta 0$ & Asian, Melanesian & 2 & 2 & $6(3.5)$ \\
\hline $\operatorname{CD} 39(C$ to $T)$ & $\beta 0$ & $\begin{array}{l}\text { Mediterranean } \\
\text { Asian Indian, }\end{array}$ & 4 & 0 & $4(2.35)$ \\
\hline $\operatorname{Fr} 8 / 9(+G)$ & $\beta 0$ & Japanese & 2 & 1 & $4(2.35)$ \\
\hline IVS 2-745 (C to G) & $\beta+$ & Mediterranean & 4 & 0 & $4(2.35)$ \\
\hline IVS $1-1(\mathrm{G}$ to $A)$ & $\beta 0$ & Mediterranean & 2 & 1 & $4(2.35)$ \\
\hline IVS 1( $3^{\prime}$ end)-25bp & $\beta 0$ & Asian Indian, UAE & 2 & 1 & $4(2.35)$ \\
\hline $\operatorname{CD} 8(-A A)$ & $\beta 0$ & Mediterranean & 1 & 1 & $3(1.8)$ \\
\hline CD $5(-C T)$ & $\beta 0$ & Mediterranean & 2 & 0 & $2(1.17)$ \\
\hline$-88(\mathrm{C}$ to $A)$ & $\beta+$ & Kurds & 2 & 0 & $2(1.17)$ \\
\hline CD 82/83(-G) & $\beta 0$ & Czech, Azerbaijan & 1 & 0 & $1(0.59)$ \\
\hline IVS 2-2,3(+11, -2) & $\beta+$ & Iranian & 1 & 0 & $1(0.59)$ \\
\hline IVS $1-130$ (G to A) & $\beta 0$ & Egyptian & 1 & 0 & $1(0.59)$ \\
\hline Unknown & & & 23 & 0 & $23(14.1)$ \\
\hline Total & & & 90 & 40 & $170(100)$ \\
\hline
\end{tabular}

Table 4. Globin mutations identified by reverse- hybridization and DNA sequencing in 254 thalassemia patient and prenatal DNA sample were initially tested for 22 common mutations by reverse - hybridization (Fakher et al., 2006).

\section{Discussion}

Iran is a country which has a population with a different ethnic identity and different languages. As we saw mutation in B-globin gene will lead to thalassemia. Although, all this mutations were found in coastline areas but their geographic distribution has special characteristic properties. In most parts of the world, a small number of thalassemia mutations predominant and the most common ones tend to be those that are geographically the most widespread and presumably also the oldest. For instance, in China and Southeast Asia, four alleles account for $91 \%$ of the genes (Kazazian et al., 1986), and in the Mediterranean Basin, six mutation account for $92 \%$ of the genes (Najmabadi et al., 2002). However, mutation 619 bp deletion is predominant in India or mutations IVS I-110 and IVS II-1 are most predominant in Arab populations (El-Hazmi et al., 1995). Because of Wars and trade off between different countries in the past years there was exchange of genetic materials between different populations. In one study it show that IVS II-1, IVS I-110, IVS I1 , and CD 8/9. These mutations are the most frequent in Iran and IVS II-1(24\%) is most predominant in Khuzestan (Rahim and Abromand, 2008). In a similar work on 1217 patients 
with B- thalassemia the most predominant mutation in North part of Iran was IVS II-1(34\%) and in South part was IVS I-5(\%) (Najmabadi et al., 2002).

Najmabadi et al (2002), have studied $B$-globin mutations and claimed the most common $B$ globin mutations is IVS I-130 (G-C), which was identified in six subjects from the North of Iran, three subjects from the Southwest, as well as in one DNA of unknown geographical origin. We have found that most predominant in South was IVSII-I (34\%) follows by IVS I110(15.7\%) and CD 8/9(13.3\%) (Rahim and Abromand, 2008). Previous research work showed most predominant mutation in Pakistan is IVS I-5(37\%) therefore this mutation is most predominant in Sistan-Baloochestan (44.8\%)(Southeast of Iran) because it is a neighborhood area to Pakistan (Kazazian et al., 1984). In a work done on thalassemia patients in Hormozgan (Southern part of Iran) claimed that most predominant mutation there is IVS I-5(69\%) followed by IVS II- 1(9.6\%) (Yavarian et al., 2001).

Research work done in 8 Gulf (Arab) Countries showed that most predominant mutations are IVS I-110 and IVS II-1 followed by IVS I-5, CD39, CD6, IVS I(3' end)-25 bp del (Adekile et al., 2005). Our finding was similar to the work done in Kuwait which showed 6 mutations are most predominant involve IVS II-1, IVS I-6, CD39, IVS I-110, CD8, IVS I-1(all give 64\%) and followed by another 2 involve CD44, CD 36/37 (Kurd, Iranian types) that give 10\% of the population. We detected different $B$-thalassemia mutations in the studied chromosomes and 5 different areas from Iran which showed IVS-II-I $(G \rightarrow A)$ was the predominant mutation found in all ethnic regions. . The presence of such a high frequency of various local mutants alleles confirms support for a role of non-isolating genetically areas. In likelihood, both founder effect and natural selection caused by migration from neighboring areas have complemented each other to produce the high frequency of unique alleles within each region (Figure 4).

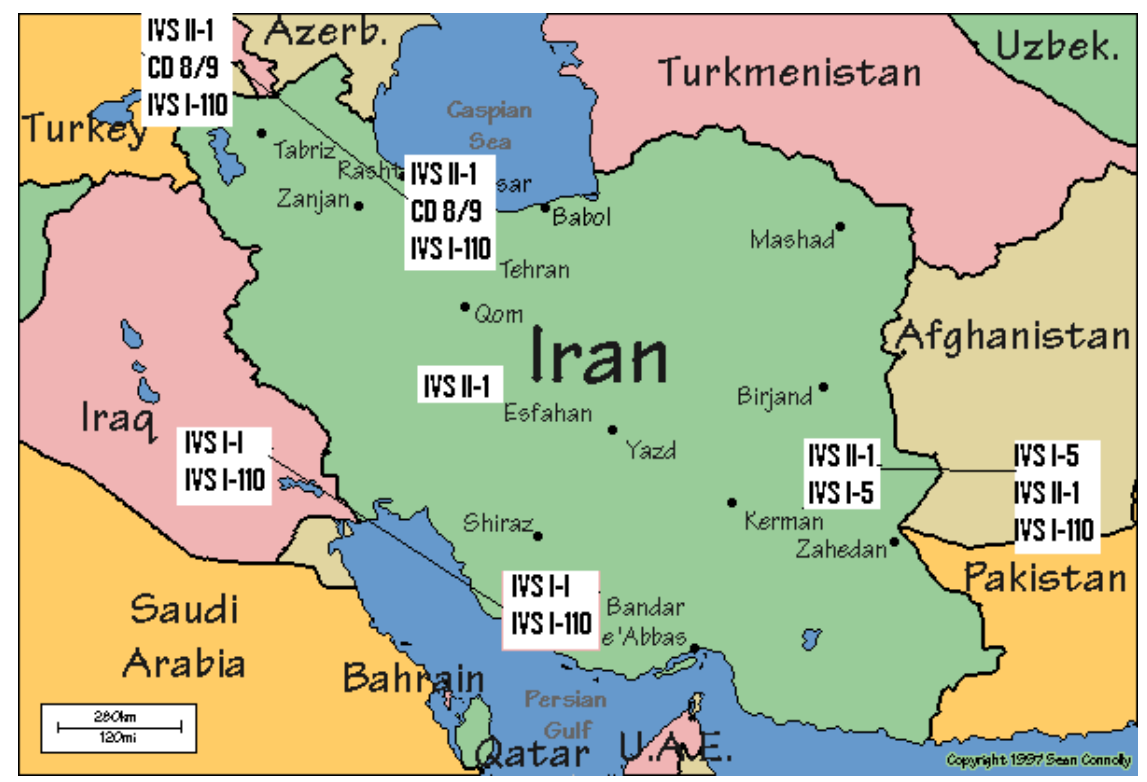

Fig. 5. The origin of mutant alleles with high frequency within different parts of Iran. The most frequent beta-gene mutations in each ethnic region indicated individually. 


\section{References}

Adekile A, Haider M, Kutlar F. Mutations Associated with Beta-Thalassemia intermedia in Kuwait. Medical Principles and Practice 2005;14(Suppl.1):69-72.

Antonarakis SE, Irkin SH, Cheng TC, Scott AF, Sexton JP, Trusko SP, et al. beta Thalassemia in American Blacks: novel mutations in the "TATA" box and an acceptor splice site. ProcNatlAcadSci USA. 1984;81(4):1154-8.

Cheng TC, Orkin SH, Antonarakis SE, Potter MJ, Sexton JP, Markham AF, et al. betaThalassemia in Chinese: use of in vivo RNA analysis and oligonucleotide hybridization in systematic characterization of molecular defects. ProcNatlAcadSci USA 1984;81(9):2821-5.

El-Hazmi MA, Warsy AS, Al-Swailem AR. The frequency of 14 beta- thalassemia mutations in the Arab populations.Hemoglobin 1995;19(6):353-60.

Fakher R, Bijan K, Taghi AM. Application of diagnostic methods and molecular diagnosis of hemoglobin disorders in Khuzestan province of Iran. Indian J Hum Genet 2007;13:5-15

Fucharoen S, Viprakasit V. Hb H disease: clinical course and disease modifiers. Hematology Am Soc Hematol Educ Program. 2009:26-34.

Galanello R, Piras S, Barella S, Leoni GB, Cipollina MD, Perseu L, et al, Cholelithiasis and Gilbert's syndrome in homozygous betathalassemia. Br J Haematol 2001. 115: 926928.

Haghshenas M, Zamani J. [Thalassemia]. 1st ed. Shiraz University of Medical Sciences Publishing Center: Shiraz; 1997. [Book in Persian]

Ho PJ, Thein SL. Gene regulation and deregulation: a beta globin perspective. Blood Rev 2000;14(2):78 -93.

Jeffreys AJ. Gene evolution. In: Genetic engineering, 2nd ed. Robert Williamson, Academic Press: 1981. p. 1-48.

Karnpean R, Fucharoen G, Fucharoen S, Sae-ung N, Sanchaisuriya K, Ratanasiri T. Accurate prenatal diagnosis of $\mathrm{Hb}$ Bart's hydrops fetalis in daily practice with a doublecheck PCR system. Acta Haematol. 2009; 121(4):227-33.

Kazazian HH, Jr, Orkin SH, Antonarakis SE, Sexton JP, Boehm CD, Goff SC, et al. Molecular characterization of seven beta - Thalassemia mutations in Asian Indians. EMBO J 1984;3(3):593-6.

Kazazian HH, Jr., Dowling CH, Waber PG, Hung S, LO, WHY.The spectrum of Beta thalassemia genes in China and Southeast Asia. Blood 1986;68:964-6.

Kazazian HH. Jr., Orkin SH, Markham AF, Chapman CR, Youssoufian H, Waber PG. On the origin and spread of beta-thalassemia: recurrent observation of four mutations in different ethnic groups. Nature 1984;310:152-4.

Najmabadi H, Ali A. Pourfathollah, Neishabury M, Sahebjam F. Rare and unexpected mutations among Iranian $B$-thalassemia patients and prenatal samples discovered by reverse-hybridization and DNA sequencing. Haematologica 2002;87(10).

Najmabadi H, Ghamari A, Sahebjam F, Kariminejad R, Hadavi V et al. Fourteen -Years Experience of Prenatal Diagnosis of Thalassemia in Iran. Com Gen 2006; 9:93-97.

Ohba Y, Hattori Y, Harano K, Fukumaki Y, Ideguchi H. ß-thalassemia mutations in Japanese and Koreans. Hemoglobin 1997;21:191-200.

Oliveri NF. The beta- thalassemias. New Eng J Med 1999;341:99-109. 
Orkin SH, Kazazian HH, JrAntonarakis SE, Goff SC, Boehm CD, Sexton JP, et al. Linkage of beta - thalassemia mutations and beta-globin gene polymorphisms with DNA polymorphisms in human beta-globin gene cluster. Nature 1982;296(5858):627-31.

Panigrahi I, Marwaha RK, Kulkarni K. The expanding spectrum of thalassemia intermedia. Hematology. 2009 Dec; 14(6):311-4.

Rahim F, Abromand M. spectrum of $\beta$-thalassemia mutations in various ethnic regions of Iran. Pak J Med Sci 2008 ;24(3):410-15

Rahim F, Kaikhaei B, Zandian K, Hoseini A. Co-inheritance of alpha-and beta-thalassemia in Khuzestan Province, Iran. Hematology. 2008 Feb; 13(1):59-64.

Rahim F, Keikhaei B, Aberumand M. Prenatal Diagnosis (PND) of $\beta$-Thalassemia in the Khuzestan Province, Iran. Journal of Clinical and Diagnostic Research. 2007Dec; 1(6):454-459

Rahim F, Keikhaei B. Better differential diagnosis of iron deficiencyanemia from betathalassemia trait. Turk J Hematol. 2009; 26(3): 138-145

Rahim F. Correlation of beta-thalassemia mutations with alpha-thalassemia: an experience of the southwestern region of Iran. Hematology. 2010 Dec; 15(6):430-3.

Rahim F. Microcytic hypochromic anemia patients with thalassemia: genotyping approach. Indian J Med Sci. 2009 Mar; 63(3):101-8.

Sack GH. Autosomal recessive disorders.Medical Genetics, McGraw-Hill, New York. 1999;61-3.

Singer ST. Variable clinical phenotypes of alpha-thalassemia syndromes. ScientificWorldJournal. 2009 Jul 13; 9:615-25.

Taher AT, Otrock ZK, Uthman I, Cappellini MD, Thalassemia and hypercoagulability. Blood Rev 2008. 22: 283-292.

Trent RJ. Medical Genetics.Molecular Medicin, Longman Singapore Ltd., Singapore. 1997;37-717.

Vichinsky EP. Alpha thalassemia major--new mutations, intrauterine management, and outcomes. Hematology Am Soc Hematol Educ Program. 2009:35-41.

Vrettou C, Traeger-Synodinos J, Tzetis M, Malamis G, Kanavakis E, Rapid screening of multiple betaglobin gene mutations by real-time PCR on the LightCycler: application to carrier screening and prenatal diagnosis of thalassemia syndromes. Clin Chem 2003. 49: 769-776.

Weatherall DJ, Clegg JB, Higgs DR, Wood WG. The hemoglobinopathies.The Metabolic and Molecular Bases of Inherited Disease.McGraw - Hill, New York. 1989;3417-83.

Yavarian M, Harteveld CL, Batelaan D, Bernini LF, Giordano PC. Molecular spectrum of beta-thalassemia in the Iranian Province of Hormozgan. Hemoglobin. 2001 Feb;25(1):35-43. 


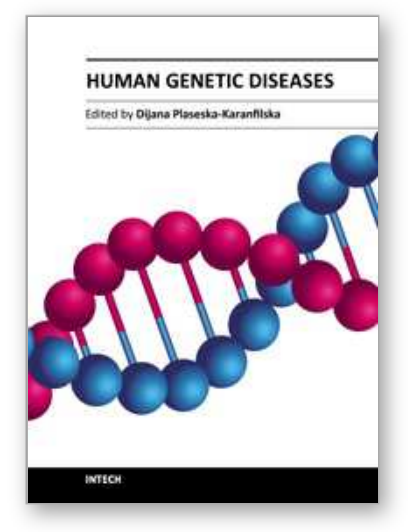

\author{
Human Genetic Diseases \\ Edited by Dr. Dijana Plaseska-Karanfilska
}

ISBN 978-953-307-936-3

Hard cover, 286 pages

Publisher InTech

Published online 30, September, 2011

Published in print edition September, 2011

The genetics science is less than 150 years old, but its accomplishments have been astonishing. Genetics has become an indispensable component of almost all research in modern biology and medicine. Human genetic variation is associated with many, if not all, human diseases and disabilities. Nowadays, studies investigating any biological process, from the molecular level to the population level, use the â€œgenetic approachâ€ to gain understanding of that process. This book contains many diverse chapters, dealing with human genetic diseases, methods to diagnose them, novel approaches to treat them and molecular approaches and concepts to understand them. Although this book does not give a comprehensive overview of human genetic diseases, I believe that the sixteen book chapters will be a valuable resource for researchers and students in different life and medical sciences.

\title{
How to reference
}

In order to correctly reference this scholarly work, feel free to copy and paste the following:

Fakher Rahim, Najmaldin Saki and Mohammad Ali Jalalai far (2011). The Role of Gene Mutations Detection in Defining the Spectrum of $B-$ Thalassemia in Various Ethnic Regions, Human Genetic Diseases, Dr. Dijana Plaseska-Karanfilska (Ed.), ISBN: 978-953-307-936-3, InTech, Available from:

http://www.intechopen.com/books/human-genetic-diseases/the-role-of-gene-mutations-detection-in-definingthe-spectrum-of-thalassemia-in-various-ethnic-regio

\section{INTECH}

open science | open minds

\section{InTech Europe}

University Campus STeP Ri

Slavka Krautzeka 83/A

51000 Rijeka, Croatia

Phone: +385 (51) 770447

Fax: +385 (51) 686166

www.intechopen.com

\section{InTech China}

Unit 405, Office Block, Hotel Equatorial Shanghai

No.65, Yan An Road (West), Shanghai, 200040, China

中国上海市延安西路65号上海国际贵都大饭店办公楼 405 单元

Phone: +86-21-62489820

Fax: $+86-21-62489821$ 
(C) 2011 The Author(s). Licensee IntechOpen. This chapter is distributed under the terms of the Creative Commons Attribution-NonCommercialShareAlike-3.0 License, which permits use, distribution and reproduction for non-commercial purposes, provided the original is properly cited and derivative works building on this content are distributed under the same license. 